\title{
Industrial Perspective on Public Private Partnerships Model in Indonesia
}

\author{
Ngo Thi Thom \\ Foreign Language Faculty \\ Nam Dinh University of Technology Education \\ Hanoi, Vietnam
}

\author{
Arie Wardhono \\ Civil Engineering Department \\ Universitas Negeri Surabaya \\ Surabaya, Indonesia \\ ariewardhono@unesa.ac.id
}

\begin{abstract}
The partnership model between vocational educational institutions and industries, known as PublicPrivate Partnership (PPP), plays an important role to overcome the skill gaps requirement between vocational educational institutions graduates and industries. The aim of this research is to provide information and feedback on understanding the perspective of industries in PPP model. The research method was focused on quantitative descriptive approach by questionnaire dispersion. This research involved 20 engineering industries in Indonesia. The results showed that the implementation of PPP improved the cooperation between vocational educational institutions and industries, and produced more highly skills workers in terms of industries perspective. This attributes to the job-related work process for the students during their learning process. However, the challenges of PPP model is an inadequate investment in training infrastructure, facilities and staff development due to the lack of government support, and the mismatch between the industries requirement and the vocational educational institutions. In general, it can be concluded that the implementation of PPP will significantly reduce the skill gaps problems.
\end{abstract}

Keywords-PPP model, industrial perspective, educational institutions, industries

\section{INTRODUCTION}

Indonesia as the member countries of ASEAN Economic Community (MEA) has big potential and opportunity. Indonesia's strength lies in the high macro-economic growth. Indonesia's large population of about 250 million people is a distinct advantage in human resources provision. However, the main problem is the relatively low competitiveness and productivity of labor, which is caused by the low level of labor education [1-2]. This results in a big gap between the job seeker skills and the competency needed by the industries. A synergy between vocational educational (VE) institutions and industries is a solution to address the gap problems between the output of VE institutions and the industries requirement [3-5].

Public-Private Partnership (PPP) is a collaboration model between VE institutions and industries in order to improve the quality of training delivered by VE institution systems and to reduce the skill gaps required by industries. The role of PPP which is improving the quality of human resources is not only the responsibility of VE institutions. However, it is a joint responsibility between government, educational institutions, and industries. In producing professional and competence in human resources, VE institutions must be supported by industries. Likewise, with the industries, it must be encouraged by $\mathrm{VE}$ institutions in order to win the competition. However, the implementation of PPP model that has been done has not shown a significant results in the absorption of VE institutions graduates [6-11]. Thus, this research aims to identify the perspective of industries, particularly on the engineering field, towards the implementation of the PPP model.

\section{METHOD}

The subjects of this research were 20 industries in East Java province, Indonesia. It involved electrical, mechanical, civil, and informatics engineering fields, respectively. The research instrument used survey questionnaire. The data was collected by content analysis based on a questionnaire. The descriptive quantitative approach was used to analyze the data. The industries sample distributions were listed in Table 1.

TABLE I. DISTRIBUTION OF INDUSTRIES

\begin{tabular}{|l|c|c|c|c|}
\hline \multirow{2}{*}{ Samples } & \multicolumn{4}{|c|}{ Number of Samples Distribution } \\
\cline { 2 - 5 } & Electrical & Mechanical & Civil & Informatics \\
\hline Industries & 6 & 7 & 10 & 7 \\
\hline
\end{tabular}

The research instrument to identify the perspective of industries on PPP implementation was determined based on the list of questionnaires in Table 2.

TABLE II. RESEARCH INSTRUMENT OF INDUSTRIES PERSPECTIVE ON PPP IMPLEMENTATION

\begin{tabular}{|c|c|c|}
\hline No & $\begin{array}{c}\text { Perspective on } \\
\text { Industries }\end{array}$ & Research Variable \\
\hline \multirow{5}{*}{1} & \multirow{5}{*}{$\begin{array}{l}\text { Background } \\
\text { factors influenced } \\
\text { the decision for } \\
\text { implementing } \\
\text { PPP }\end{array}$} & Support by government initiative \\
\hline & & Closer cooperation with industries \\
\hline & & To produce highly skills workers \\
\hline & & More interaction \\
\hline & & Sharing knowledge on new technology \\
\hline \multirow[t]{4}{*}{2} & \multirow{4}{*}{$\begin{array}{l}\text { Advantages from } \\
\text { PPP }\end{array}$} & Skills training are more business driven \\
\hline & & $\begin{array}{l}\text { Employee aware of what is happening in } \\
\text { industries }\end{array}$ \\
\hline & & $\begin{array}{l}\text { Employee learn to operate latest stage of } \\
\text { equipment and technology }\end{array}$ \\
\hline & & Student learn by job-related work processes \\
\hline \multirow[t]{2}{*}{3} & \multirow[t]{2}{*}{ Benefits of PPP } & Produce more skilled students \\
\hline & & $\begin{array}{l}\text { Prepare persons for employment in a } \\
\text { recognize occupation }\end{array}$ \\
\hline
\end{tabular}




\begin{tabular}{|c|c|c|}
\hline No & $\begin{array}{l}\text { Perspective on } \\
\text { Industries }\end{array}$ & Research Variable \\
\hline & & Reduce costs and increase revenues \\
\hline & & To produce highly skills workers \\
\hline \multirow[t]{3}{*}{4} & \multirow[t]{3}{*}{$\begin{array}{l}\text { The challenges of } \\
\text { PPP }\end{array}$} & $\begin{array}{l}\text { Mismatch between the labor market and } \\
\text { TVET program }\end{array}$ \\
\hline & & $\begin{array}{l}\text { Training needs are not always identified and } \\
\text { prioritized according to industry skills and } \\
\text { workforce development }\end{array}$ \\
\hline & & $\begin{array}{l}\text { Inadequate investment in training } \\
\text { infrastructure, facilities, and staff } \\
\text { development }\end{array}$ \\
\hline
\end{tabular}

\section{RESULT AND DISCUSSION}

The perspective of industries on PPP model implementation was determined by four (4) factors as follows: (1) the background factors that influenced the decision from PPP implementation, (2) the advantages of PPP model which industries expected, 3 ) the benefits of PPP model for industries, and 4) the challenges of PPP implementation.

\section{A. The background factors that influenced the decision from PPP implementation.}

Fig. 1 shows the results on the background factors that influenced the decision from the implementation of the PPP model for the industries based on the questionnaire results.

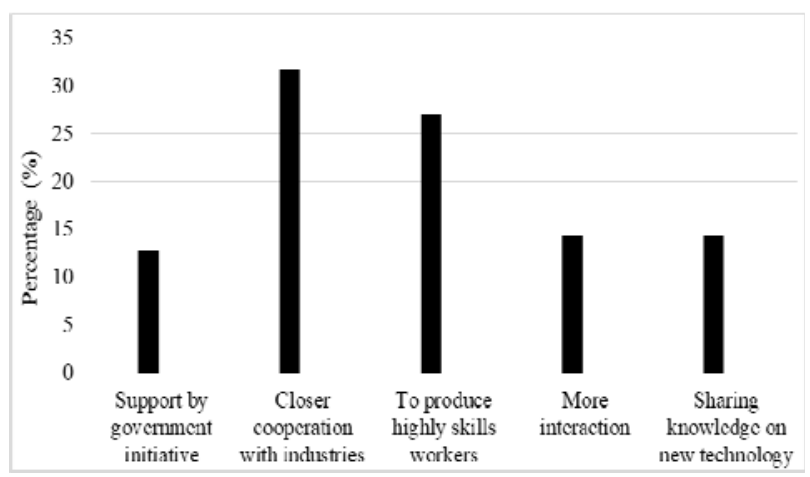

Fig. 1. Background factors that influenced the decision from PPP model implementation

There are five variables that determine the background factors which influenced the decision of from PPP model implementation: support by government initiative, closer cooperation with industries, to produce highly skills workers, more interaction between VE institutions and industries, and sharing knowledge on new technology.

According to industries perspective, the implementation of PPP model is important especially to improve the relationship and cooperation between VE institutions and industries. Further, this type of cooperation will produce a highly skills workers which will meet the skills requirement of the industries. However, the low support and involvement of government in the PPP program, particularly to the industries, has resulted in uncertainty about the sustainability of the PPP implementation. Thus, this results in low interaction between VE institutions and industries. Further, with the uncertainty of government role and policy, the industries is reluctant to share new technology during PPP implementation.

\section{B. The advantages expected from PPP implementation.}

Fig. 2 exhibits the advantages that industries expected from the implementation of the PPP model. The advantages expected are consisted of: skill training are more business driven, employee aware of what is happening in industries, employee learn to operate the latest stage, and student learn by job-related work processes.

The results show that the implementation of PPP model provides a significant benefit to industries. Vocational students from VE institutions learn by job-related work processes for a longer duration than the practical work model. The job-related work training provides the students with skills and abilities that needed by the industries. This will benefit the industries because the industries get VE institutions graduates who are ready to work in accordance with the industries requirement. The industries do not even have to provide training expense for new staff.

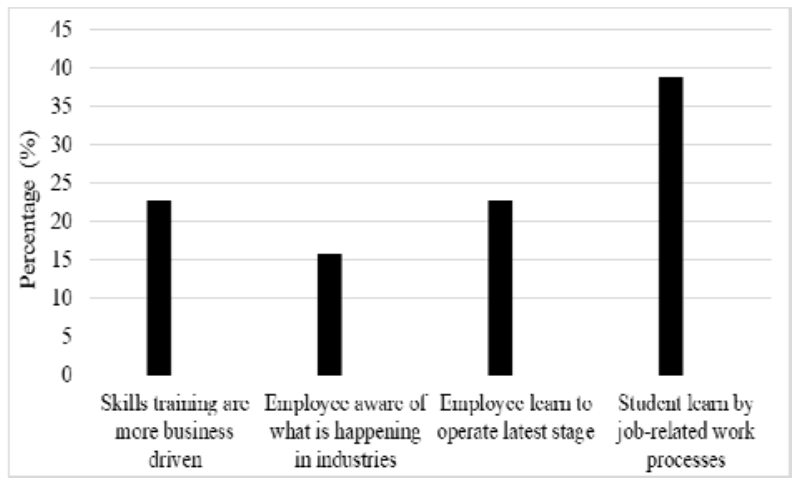

Fig. 2. The advantages expected from PPP model implementation

C. The benefits of PPP implementation

Fig. 3 displays the benefits of PPP implementation.

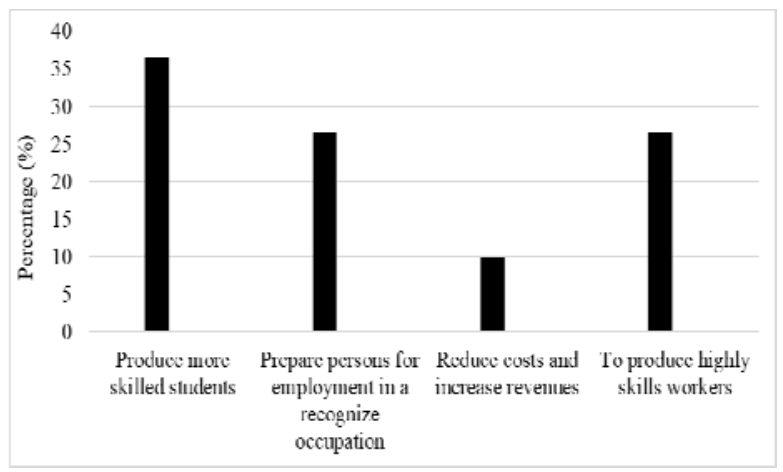

Fig. 3. The advantages expected from PPP model implementation

The benefits variables in this research are: produce more skills students, prepare persons for employment in a recognized occupation, reduce costs and increase revenues, and to produce highly skills workers.

According to Figure 3, the implementation of the PPP model brings benefits to the industries. The involvement of students in industries during their studies produce more skilled students and prepared the students for employment in a recognized occupation in industries. This is because the students can feel directly the work atmosphere in industries and the type of work that must be faced after they graduate. Further, this results a high skilled graduate students. 


\section{The challenges of PPP implementation}

The challenges of PPP implementation on industries perspective can be seen in Figure 4. The first challenge is inadequate investment in training infrastructure, facilities, and staff development. This is attributed to the low support from the government as shown in previous results in Fig. 4.

The second challenges in the discrepancy between training developed by the VE institutions with the industrial needs. The module or training programs developed by VE institutions are not always identified and prioritized according to industry skills. This can be seen by high unemployment rate in Indonesia. According to ASEAN Statistical Year Book [12] and Indonesia Statistical Department [13], the unemployment rate in Indonesia is the second higher (6.2\%), next to Philippines (6.4\%) in ASEAN region and dominated by VE institutions graduates (26\%).

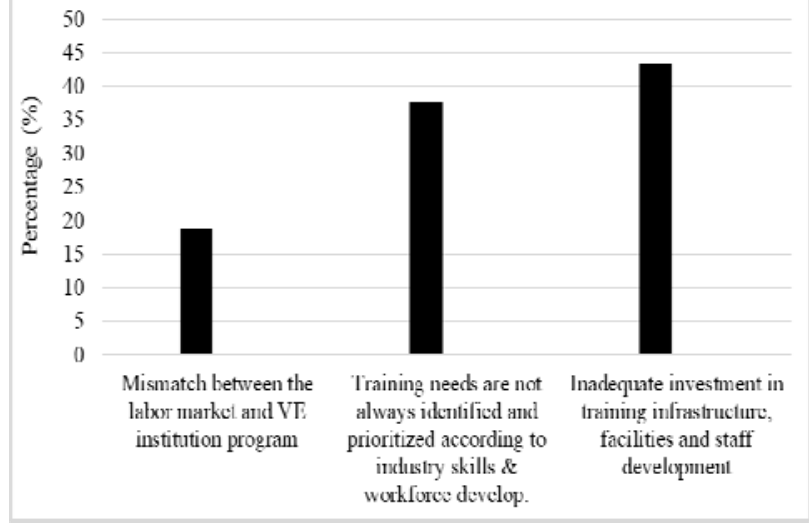

Fig. 4. The challenges of PPP model implementation

The third challenge is the mismatch between the labor market and the VE institution program. Despite the government has opened many vocational schools, the determination of vocational school field does not consider the requirement of industries. Further, similar to the previous findings in Figure 1, the interaction between VE institutions and industries does not indicate a good relationship.

\section{E. The perspective of industries on PPP implementation}

The perspectives of industries towards the implementation of the PPP model are shown in Fig. 5.

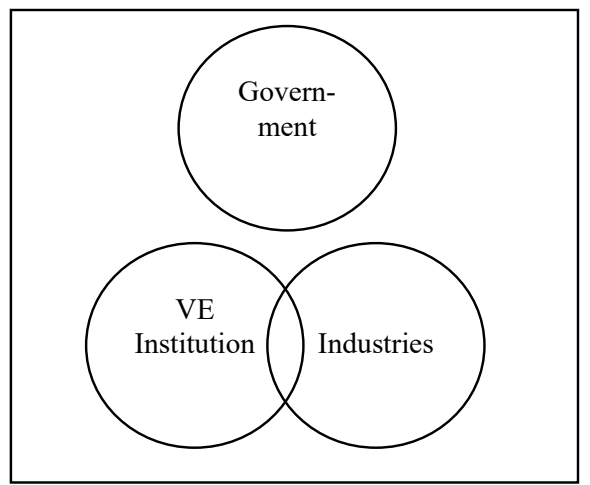

Fig. 5. The perspective of industries on PPP model implementation

According to the industries perspective which is derived from the results analysis, there is no definite relationship between the role of government, VE institutions as the supplier of vocational graduates, and industries as the users of VE institutions output (vocational graduates). The low role of government in addressing the PPP implementation has resulted in infrastructure, facilities, and staff development of VE institutions being hampered and unable to meet the needs of the industries requirement. In addition, the lack of communication between VE institutions and industries has an impact on the lack of synchronization between the VE institutions program and the industrial needs.

\section{CONCLUSION}

This research deals with the industrial perspective on the implementation of the PPP model in Indonesia. The main conclusion based on the industrial perspective which can be drawn from this research are as follows:

- The implementation of PPP improved the cooperation between vocational educational institutions and industries and produced more highly skills workers

- The main advantage of the implementation of PPP is the student can learn from job-related processes which can prepare the student before they work.

- The benefits of PPP implementation are producing more skilled students which lead to the high skills workers.

- The challenges of PPP implementation is an inadequate investment in training infrastructure, facilities and staff development due to the lack of government support, and the mismatch between the industries requirement and the vocational educational institutions.

- The implementation of PPP will significantly reduce the skill gaps problems.

\section{REFERENCES}

[1] F. Sjoholm, "Productivity Growth in Indonesia: The Role of Regional Characteristics and Direct Foreign Investment," Economic Development and Culture Change, vol. 47, no. 3, April 1999.

[2] E. Duflo, "Schooling and Labor Market Consequences of School Construction in Indonesia: Evidence from an Unusual Policy Experiment," American Economic Review, vol. 91, no. 4, pp. 795813, September 2001.

[3] K. Morgan, "The Learning Region: Institutions, Innovation and Regional Renewal," Journal of Regional Studies, vol. 41, 2007.

[4] A. Azevedo, G. Apfelthaler, and D. Hurst, "Competency Development in Business Graduates: An Industry-driven Approach for Examining The Alignment of Undergraduate Business Education with Industry Requirements," The International Journal of Management Education, vol. 10, issue 1, pp. 12-28, April 2012.

[5] D. Mavrikios, N. Papakostas, D. Mourtzis, and G. Chryssolouris, "On Industrial Learning and Training for The Factories of The Future: A Conceptual, Cognitive and Technology Framework," vol. 24, issue 3, pp. 473-485, June 2013.

[6] D.W. Brinkerhoff and J.M. Brinkerhoff, "Public-Private Partnerships: Perspectives on Purposes, Publicness and Good Governance," Public Administration and Development, vol. 31, issue 1, pp. 2-14, February 2011.

[7] A. Hall, "Public-Private Sector Partnership in an Agricultural System on Innovation: Concepts and Challenges," International Journal of Technology Management \& Sustainable Development, vol. 5, no. 1, pp. 3-20, April 2006

[8] H. Pillay, J.J. Watters, and L. Hoff, "Critical Attributes of PublicPrivate Partnerships: A Case Study in Vocational Education," International Journal of Adult Vocational Education and Technology (IJAVET), vol. 4, issue 1, 2013. 
[9] J. Sung, "Vocational Education and Training and Engagement: An Industry-led System in The Netherlands," International Journal of Training and Development, vol. 14, issue 1, pp. 16-31, March 2010.

[10] P. Brimble and R.F. Doner, "University-Industry Linkages and Economic Development: The Case of Thailand, " World Development, vol. 35, issue 6, pp. 1021-1036, June 2007.

[11] R. Mazzoleni and R.R. Nelson, "Public Research Institutions and Economic Catch-up," Research Policy, vol. 36, issue 10, pp. 15121528, December 2007.

[12] The ASEAN Secretariat, “ASEAN Statistical Year Book 2014,” 2015

[13] Indonesia Statistical Department (Badan Pusat Statistik Indonesia), https://www.bps.go.id/ 